\title{
Animal performance and nutritional characteristics of Piatã-grass in integrated systems
}

[Desempenho animal e características nutricionais de capim-piatã em sistemas integrados]

\author{
D.C. Martins ${ }^{1}$, S.D.J. Villela ${ }^{1 *}$, R.G. Almeida ${ }^{2}$, S.A.C. Araújo ${ }^{3}$, \\ L.D. Silva ${ }^{1}$, J.R. Paschoaloto ${ }^{1}$, P.G.M.A. Martins ${ }^{1}$
}

\begin{abstract}
${ }^{1}$ Universidade Federal dos Vales do Jequitinhonha e Mucuri - Diamantina, MG
${ }^{2}$ Embrapa - Centro Nacional de Pesquisa de Gado de Corte - Campo Grande, MS ${ }^{3}$ Instituto de Ciências Agrárias - Universidade Federal dos Vales do Jequitinhonha e Mucuri - Unaí, MG
\end{abstract}

\begin{abstract}
The objective was to evaluate animal performance and nutritional characteristics of Brachiaria brizantha cv. BRS Piatã in two integrated systems, during the summer and winter, five years after the initial establishment of the area. The randomized block experimental design was adopted with treatments consisting of a control (five native trees per hectare) and an integrated crop-livestock-forestry (ICLF) system with 227 eucalyptus trees per hectare. Animal performance, canopy height, soil cover, forage mass (leaf, stem and senescent material), and forage nutritive value were evaluated. Differences between systems were observed in forage mass (total, leaf, stem and senescent material), soil cover and forage nutritive value in both seasons. Shading conditions provided by eucalyptus in the ICLF system lead to a reduction in forage mass and neutral detergent fiber content, and to an increase in crude protein and in vitro organic matter digestibility. However, no effect on animal performance was obtained. The presence of trees improves the forage nutritive value without impacting animal performance in integrated systems.
\end{abstract}

Keywords: agrosilvopastoral systems, forage yield, integrated crop-livestock-forest system, Urochloa brizantha

\section{RESUMO}

O objetivo foi avaliar o desempenho animal e as características nutricionais de Brachiaria brizantha $c v$. BRS Piatã em dois sistemas integrados, durante o verão e o inverno, cinco anos após o estabelecimento inicial da área. O delineamento experimental em blocos ao acaso foi adotado com tratamentos constituídos por um controle (cinco árvores nativas por hectare) e um sistema integrado lavoura-pecuária-floresta (ILPF) com 227 eucaliptos por hectare. Desempenho animal, altura do dossel, cobertura do solo, massa de forragem (folha, caule e material senescente) e valor nutritivo da forragem foram avaliados. Diferenças entre os sistemas foram observadas na massa de forragem (total, foliar, caule e material senescente), na cobertura do solo e no valor nutritivo da forragem em ambas as estações. As condições de sombreamento proporcionadas pelo eucalipto no sistema ICLF levaram a uma redução na massa de forragem e no teor de fibra em detergente neutro e a um aumento na proteína bruta e na digestibilidade in vitro da matéria orgânica. No entanto, nenhum efeito no desempenho animal foi obtido. A presença de árvores melhora o valor nutritivo da forragem, sem impactar o desempenho animal em sistemas integrados.

Palavras-chave: produção de forragem, sistemas agrossilvopastoris, sistemas integrados lavourapecuária-floresta, Urochloa brizantha

Recebido em 25 de setembro de 2018

Aceito em 1 de outubro de 2019

*Autor para correspondência (corresponding author)

E-mail: svillela@ufvjm.edu.br 


\section{INTRODUCTION}

Agrosilvopastoral systems have been used as an alternative to diversify land use, in a sustainable and rational manner in which crop, livestock, and forestry are conducted simultaneously or sequentially (Young, 1997). These systems are used to reestablish degraded pasture areas and have a potential to improve animal comfort, soil fertility, forage quality, and carbon sequestration, in addition to diversifying revenue sources for producers without decreasing animal production (Murgueitio et al., 2011; Oliveira et al., 2014; Paciullo et al., 2014, 2017).

In Brazil, producers are increasingly employing integrated systems since tree planting is recommended as an alternative to restore degraded pasture areas because of the diversity of species in these systems, and crop rotation makes it possible to control soil erosion, reduces soil compaction and improves soil properties (DiasFilho, 2006, 2015). On the other hand, shade from trees may restrict forage yield, especially in tropical grasses. Some species are tolerant to moderate degree of shading, depending on plant ability to adapt, morphologically and physiologically, to a given light level (Dias-Filho, 2000). This acclimation capacity to a reduced light environment is important to determine their competitive potential in that specific environment (Dias-Filho, 1997, 2006; Nandal et al., 1999).

Reduction in pasture productivity has important implications when selecting shade-tolerant grass species to be utilized in integrated systems, especially because forage production is directly related with animal performance. According to Euclides et al. (2009), leaf availability has a great correlation with intake, grazing time and body weight (BW) gain of animals. In this sense, studies evaluating the interaction between trees, grasses and animal production are needed. Brachiaria brizantha is classified as medium tolerant to shade (Shelton et al., 1987; Humphreys, 1991). However, few studies reporting evaluation of the Piatã cultivar in integrated crop-livestock and/or crop-livestockforestry systems are available in the literature. Thus, the objective herein was to evaluate animal performance and nutritional characteristics of Piatã-grass (Brachiaria brizantha cv. BRS Piatã) in integrated systems during summer and winter.

\section{MATERIAL AND METHODS}

Animals utilized in this study were cared for by acceptable practices and all research procedures were approved by the Institutional Committee of Ethics on the Use of Animals from Embrapa National Center for Beef Cattle Research (protocol number 014/2014).

The experiment was conducted from December 2013 to August 2014 at the Embrapa National Center for Beef Cattle Research, in Campo Grande, Mato Grosso do Sul State, Brazil $\left(54^{\circ} 37^{\prime} \mathrm{W}, \quad 20^{\circ} 27^{\prime} \mathrm{S}\right.$, and $530 \mathrm{~m}$ altitude). According to the Köppen-Geiger climate classification (Kottek et al., 2006), the experimental area is located in the transition between Cfa and AW tropical humid. During the experimental period, the average minimum and maximum temperatures were 20.1 and $25.5^{\circ} \mathrm{C}$, and the monthly minimum and maximum rainfall average values were 17.7 and $170.8 \mathrm{~mm}$, respectively (Table 1).

The experimental site, established in 2008 as a strategy of pasture restoration by cultivating soybean followed by Piatã-grass (previously described by Oliveira et al., 2014, 2018), consisted of two integrated crop-livestockforestry (ICLF) systems and one integrated croplivestock system. However, in the present study, only one ICLF system was evaluated. Soil was classified as dystrophic red latosol with clayey texture, with the following chemical characteristics in the 0 to $20 \mathrm{~cm}$ layer at the beginning of the experiment: clay content of $41 \pm 5 \%$; Mehlich-1 extractable $\mathrm{P}$ ranging from 0.29 to $0.42 \mathrm{mg} \mathrm{dm}^{-3}$; base saturation ranging from $26 \%$ to $34 \%$; and aluminum saturation ranging from $10 \%$ to $23 \%$.

Treatments consisted of two integrated systems: (1) ICLF system, with simple wide spaced tree (Eucalyptus grandis x Eucalyptus urophylla; $\mathrm{H} 13$ clone) rows, $22 \times 2 \mathrm{~m}$ tree spacing and 227 trees per hectare; and (2) an integrated crop-livestock system (control; CTRL), with five scattered native trees (Gochnatia and Dipteryx species) per hectare, which is commonly found in ordinary production systems of the region. During the experimental period, the initial and final average ICLF tree height was 25 and $27 \mathrm{~m}$, respectively. 
Table 1. Monthly average temperature and rainfall at the Embrapa National Center for Beef Cattle Research, in Campo Grande, Mato Grosso do Sul State, Brazil (54 $37^{\prime} \mathrm{W}, 20^{\circ} 27^{\prime} \mathrm{S}$, and 530m altitude) in 2013 and 2014

\begin{tabular}{lllll}
\hline & \multicolumn{2}{l}{ Temperature $\left({ }^{\circ} \mathrm{C}\right)$} & \multicolumn{2}{l}{ Rainfall $(\mathrm{mm})$} \\
\cline { 2 - 5 } Month & 2013 & 2014 & 2013 & 2014 \\
\hline January & 25.5 & 24.6 & 218.3 & 162.3 \\
February & 24.7 & 25.1 & 215.8 & 111.8 \\
March & 24.9 & 24.3 & 187.2 & 163.3 \\
April & 22.5 & 24.1 & 210.8 & 52.6 \\
May & 22.2 & 20.6 & 14.9 & 165.5 \\
June & 21.0 & 20.7 & 36.5 & 51.1 \\
July & 19.7 & 20.1 & 0.0 & 115.2 \\
August & 20.2 & 23.0 & 0.0 & 17.7 \\
September & 23.4 & 25.5 & 105.5 & 66.0 \\
October & 24.5 & 27.0 & 122.2 & 19.7 \\
November & 25.2 & 24.7 & 249.6 & 217.8 \\
December & 25.5 & 24.9 & 170.8 & 359.4 \\
\hline
\end{tabular}

The experimental area was divided into four 1.5ha paddocks (two paddocks for each treatment). A continuous grazing method was adopted for pasture management with varying stocking rate. A total of ten Nellore heifers (initial $\mathrm{BW}=180 \pm 13.6 \mathrm{~kg}$ ) were randomly assigned to paddocks and an extra area, adjacent to the experimental site. In each paddock, two heifers were used to evaluate animal performance, and the remaining heifers were used to keep predetermined sward heights in a put-and-take stocking management. Heifers had free-choice access to water and commercial mineral supplement throughout the experiment. Individual heifer BW was measured every 28 days after a 16hour period of water and feed withdrawal. Average daily gain (ADG) and BW gain per hectare were calculated to assess animal performance. In addition, stocking rate, calculated as the number of animal units (considering a $450 \mathrm{~kg}$ adult animal) per hectare, was determined.

Forage assessments were performed every 28 days. Ten forage samples were randomly collected from each paddock, in each system. A $1.0 \mathrm{~m}^{2}$ square plot was used to assess total biomass, which was obtained by clipping and harvesting all above ground forage parts. Canopy height was measured by using a graduated ruler before forage clipping. Forage was clipped at the ground level by using an electric clipper. Soil cover was visually appraised after forage harvesting. The harvested material was weighed to estimate forage production and transferred to the laboratory to sort leaf lamina, stem sheath, and senescent material. Each component was dried at $55^{\circ} \mathrm{C}$ in a forced-air oven to a constant weight, and then forage mass values were measured.

To evaluate nutritive value, leaf and stem sheath samples were ground in a Wiley mill (Thomas Model 4 Wiley Mill; Thomas Scientific, Swedesboro, NJ, USA) to pass through a 1-mm stainless steel curved round-hole sieve. Samples were analyzed for dry matter (DM), crude protein (CP), neutral detergent fiber (NDF), and in vitro organic matter digestibility (IVOMD) using a near-infrared spectroscopy (model NR 5000, Metrohm NIRS Systems, Herisau, Switzerland), according to the method described by Marten et al. (1989).

The randomized block experimental design was utilized with two replicates for animal performance evaluation and four replicates for forage characteristics assessment. Evaluations were performed during the summer (December, January, and February) and winter (June, July, and August). Data were subjected to analysis of variance and means were separated for comparison by F-test using the GLM procedure of SAS (version 9.1; SAS Institute Inc., Cary, NC, USA). Significance was set at $\mathrm{P} \leq 0.05$.

\section{RESULTS}

For animal performance, no differences $(\mathrm{P}>0.19)$ were observed between systems for ADG, stocking rate, and BW gain in both seasons (Table 2). 
Table 2. Performance of Nellore heifers in integrated crop-livestock-forest (ICLF) and crop-livestock (control; CTRL) systems

\begin{tabular}{|c|c|c|c|c|c|c|c|c|}
\hline \multirow{2}{*}{ Item } & \multicolumn{4}{|c|}{ Summer } & \multicolumn{4}{|c|}{ Winter } \\
\hline & ICLF & CTRL & SEM & $P$-value & ICLF & CTRL & SEM & $P$-value \\
\hline Stocking rate $\left(\mathrm{AU} \mathrm{ha}^{-1}\right)^{\mathrm{a}}$ & 3.3 & 3.6 & 0.1 & 0.5160 & 1.2 & 1.18 & 0.01 & 0.3118 \\
\hline $\begin{array}{l}\text { Average daily gain (g } \\
\left.\text { animal }^{-1} \text { day }^{-1}\right)\end{array}$ & 581.4 & 475.4 & 48.9 & 0.3724 & 82.5 & 272.5 & 67.9 & 0.1922 \\
\hline $\begin{array}{l}\text { Body weight gain per hectare } \\
\left(\mathrm{kg} \mathrm{ha}^{-1}\right)\end{array}$ & 268.7 & 238.6 & 24.9 & 0.6573 & 13.75 & 45.42 & 11.32 & 0.1911 \\
\hline
\end{tabular}

SEM = standard error of the mean

${ }^{\text {a }}$ Stocking rate was calculated as the number of animal units (considering a 450kg adult animal) per hectare

Differences $(\mathrm{P} \leq 0.01)$ were detected between ICLF and CTRL systems for DM content of forage components (total, leaf, and stem), canopy height, and soil cover during the summer (Table 2). In the ICLF system, a $19.7 \mathrm{~cm}$ reduction in canopy height was obtained and approximately
$30 \%$ greater soil cover was observed compared to CTRL system. During the winter, a similar effect on soil cover was observed. During the summer, canopy height was shorter in ICLF than CTRL, consequently resulting in greater total DM (Table $3)$.

Table 3. Characteristics and forage mass of Piatã-grass (Brachiaria brizantha cv. BRS Piatã) in integrated crop-livestock-forest (ICLF) and crop-livestock (control; CTRL) systems during summer and winter

\begin{tabular}{lllllllll} 
& \multicolumn{7}{l}{ Summer } & \multicolumn{7}{c}{ Winter } & \\
\cline { 2 - 7 } Item & ICLF & CTRL & SEM & $P$-value & ILCLF & CTRL & SEM & $P$-value \\
\hline Canopy height (cm) & 78.7 & 98.4 & 2.6 & 0.0010 & 32.6 & 35.1 & 0.9 & 0.1614 \\
Soil cover (\%) & 60.7 & 86.8 & 3.4 & 0.0010 & 75.8 & 94.1 & 2.6 & 0.0001 \\
Forage mass (kg DM ha $\left.{ }^{-1}\right)$ & & & & & & & & \\
$\quad$ Total DM & 2308.0 & 3412.0 & 174.0 & 0.0141 & 1577.2 & 2433.1 & 130.1 & 0.0141 \\
$\quad$ Leaf DM & 633.9 & 1069.4 & 72.0 & 0.0006 & 271.8 & 415.2 & 25.8 & 0.0026 \\
$\quad$ Stem DM & 1401.0 & 1974.3 & 96.7 & 0.0009 & 279.6 & 460.9 & 32.1 & 0.0020 \\
$\quad$ Senescent DM & 272.5 & 368.4 & 37.0 & 0.2035 & 1025.7 & 1557.0 & 87.4 & 0.0006 \\
\hline
\end{tabular}

$\mathrm{DM}=$ dry matter; $\mathrm{SEM}=$ standard error of the mean.

Forage CP and NDF were affected by the different systems. Leaf and stem CP content was greater $(\mathrm{P}<0.01)$ in ICLF compared with CTRL. On the other hand, NDF content was greater $(\mathrm{P}<0.01)$ in
CTRL compared with ICLF. Leaf and stem IVOMD were greater $(\mathrm{P} \leq 0.03)$ in ICLF compared with CTRL (Table 4).

Table 4. Nutritive value of Piatã-grass (Brachiaria brizantha cv. BRS Piatã) components from integrated crop-livestock-forest (ICLF) and crop-livestock (control; CTRL) systems during summer and winter

\begin{tabular}{|c|c|c|c|c|c|c|c|c|}
\hline \multirow{2}{*}{ Nutritional characteristics, $\%$} & \multicolumn{4}{|c|}{ Summer } & \multicolumn{4}{|c|}{ Winter } \\
\hline & ICLF & CTRL & SEM & $P$-value & ICLF & CTRL & SEM & $P$-value \\
\hline \multicolumn{9}{|l|}{ Leaf } \\
\hline Crude protein & 10.5 & 7.7 & 0.5 & 0.0026 & 13.5 & 11.2 & 0.3 & 0.0001 \\
\hline Neutral detergent fiber & 69.9 & 72 & 0.4 & 0.0086 & 66.5 & 68.5 & 0.3 & 0.0012 \\
\hline $\begin{array}{l}\text { In vitro organic matter } \\
\text { digestibility }\end{array}$ & 54.9 & 50.5 & 0.8 & 0.0059 & 69.9 & 64.2 & 0.9 & 0.0002 \\
\hline \multicolumn{9}{|l|}{ Stem } \\
\hline Crude protein & 4.6 & 3.1 & 0.3 & 0.0010 & 5.5 & 4.9 & 0.2 & 0.0337 \\
\hline Neutral detergent fiber & 80.1 & 82.4 & 0.4 & 0.0025 & 78 & 75.8 & 0.4 & 0.0036 \\
\hline $\begin{array}{l}\text { In vitro organic matter } \\
\text { digestibility }\end{array}$ & 41.1 & 39 & 0.7 & 0.0325 & 43.9 & 47.5 & 0.7 & 0.0017 \\
\hline
\end{tabular}

SEM $=$ standard error of the mean 


\section{DISCUSSION}

The presence of trees modifies the microclimate and, because of their upper position relative to forage canopy, the tree leaves absorb light preferentially, decreasing the amount of photosynthetic active radiation that reaches the understory (Feldhake et al., 2005; Garcia et al., 2011). In the present study, the difference in forage characteristics of both integrated systems indicates that shade provided by eucalyptus affected forage mass, although the senescent material was not affected in the summer and canopy height, during the winter. Grasses, when under adverse conditions (i.e., shading), culminate in senescence and death, and consequently are not kept in the system (Givnish, 1988). In the present study, although there was shading in both summer and winter and in either system, no difference was detected; even in the winter, the senescent DM content was lower in the ICLF than in CTRL system.

According to Gómez et al. (2013), under reduced sunlight conditions, recently expanded leaves keep their functional integrity for photosynthesis during longer periods, thus the efficiency in using light is maintained. During the winter, both systems presented similar canopy height, despite the shading provided by the eucalyptus in the ICLF system. As listed in Table 1, during the winter season, the average monthly rainfall was $61.3 \mathrm{~mm}$, whereas in the summer was $148.3 \mathrm{~mm}$. It is well known that forage growth is strongly susceptible to weather conditions, especially water availability (Ludlow and $\mathrm{Ng}$, 1977).

Nutritive value of forage in the ICLF system was greater than the CTRL system, reflecting the positive influence of shade, which may be associated with a few factors. Wilson (1996) related this phenomenon to increased soil moisture, which improves organic matter degradation and nitrogen recycling. Thus, the increased $\mathrm{CP}$ content in the forage could be associated with an increased nitrogen flow into the soil. Another mechanism related with a delay in the ontogenetic development of plants cultivated under shading could explain that phenomenon (Sousa et al., 2010). In this manner, forages tend to be physiologically younger, maintaining increased metabolic levels for longer periods. Likewise, Neel et al. (2016) also observed a delay in pasture morphological maturity in an integrated system with trees compared to full sunlight system. Furthermore, the shaded conditions could reduce cell size, which, with a constant amount of $\mathrm{N}$ per cell, may have a concentrating effect (Kephart and Buxton, 1993; Garcia et al., 2011). Indeed, the reduced NDF content of the forage in the ICLF system may be associated with a decreased rate of photoassimilates for the development of the secondary cells, as well as the content of the wall and its constituents (Kephart and Buxton, 1993; Deinum et al., 1996).

The increased nutritional value of forage under shading conditions, especially as a result of high $\mathrm{CP}$, may contribute to improved animal performance (Yamamoto et al., 2007; Bocquier and González-García, 2010; Paciullo et al., 2010; Sousa et al., 2010). Nevertheless, despite ICLF system presenting higher forage nutritive value, animal performance did not differ between systems because of the decreased forage mass, especially leaf mass, which is the preferred component selected by grazing animals (Brâncio et al., 2003).

In conclusion, shade provided by eucalyptus in the ICLF system seems to be interesting because of the improvement in forage nutritive value. In addition, the eucalyptus tree at a density of 227 trees per hectare after 5 year of system establishment does not impair animal performance, even with reduction in total forage mass production.

\section{ACKNOWLEDGEMENTS}

The authors thank the Coordenação de Aperfeiçoamento de Pessoal de Nível Superior (CAPES) - Finance Code 001, and Fundect ("Fundação de Apoio ao Desenvolvimento do Ensino, Ciência e Tecnologia do Estado de Mato Grosso do Sul') for financial support. In addition, the authors express appreciation to the staff from the Embrapa National Center for Beef Cattle Research for assistance during this study.

\section{REFERENCES}

BOCQUIER, F.; GONZÁLEZ-GARCÍA, E. Sustainability of ruminant agriculture in the new context: feeding strategies and features of animal adaptability into the necessary holistic approach. Animal, v.4, p.1258-1273, 2010. 
BRÂNCIO, P.A.; NASCIMENTO JUNIOR, D.; EUCLIDES, V.P.B. et al. Avaliação de três cultivares de Panicum maximum Jacq. sob pastejo: composição da dieta, consumo de matéria seca e ganho de peso animal. R. Bras. Zootec., v.32, p.1037-1044, 2003.

DEINUM, B.; SULASTRI, R.D.; ZEINAB, M.H.J.; MAASSEN, A. Effects of light intensity on growth, anatomy and forage quality of tropical grasses. Neth. J. Agric. Sci., v.44, p.111-124, 1996.

DIAS-FILHO, M.B. Estratégias de recuperação de pastagens degradadas na Amazônia brasileira. Belém, PA: Embrapa Amazônia Oriental, 2015. 25 p.

DIAS-FILHO, M.B. Growth and biomass allocation of the $\mathrm{C}_{4}$ grasses Brachiaria brizantha and B. humidicola under shade. Pesq. Agropec. Bras., v.35, p.2335-2341, 2000.

DIAS-FILHO, M.B. Physiological response of Solanum crinitum Lam. to contrasting light environments. Pesq. Agropec. Bras., v.32, p.789796, 1997.

DIAS-FILHO, M.B. Sistemas silvipastoris na recuperação de pastagens tropicais degradadas. Belém, PA: Embrapa Amazônia Oriental, 2006. 30 p.

EUCLIDES, V.P.B.; MACEDO, M.C.M.; VALLE, C.B. et al. Valor nutritivo da forragem $\mathrm{e}$ produção animal em pastagens de Brachiara brizantha. Pesq. Agropec. Bras., v.44, p.98-109, 2009.

FELDHAKE, C.M.; NEEL, J.P.S.; BELESKY, D.P.; MATHIAS, E.L. Light measurement methods related to forage yield in a grazed northern conifer silvopasture in the Appalachian region of eastern USA. Agroforest. Syst., v.65, p.231-239, 2005.

GARCIA，A.R.; MATOS, L.B.; LOURENÇO JÚNIOR, J.B. et al. Variáveis fisiológicas de búfalas leiteiras criadas sob sombreamento em sistemas silvipastoris. Pesq. Agropec. Bras., v.46, p.1409-1414, 2011.

GIVNISH, T.J. Adaptation to sun and shade: a whole-plant perspective. Aust. J. Plant Physiol., v.15, p.63-92, 1988.
GÓMEZ, S.; GUENNI, O.; BRAVO DE GUENNI, L. Growth, leaf photosynthesis and canopy light use efficiency under differing irradiance and soil $\mathrm{N}$ supplies in the forage grass Brachiaria decumbens Stapf. Grass Forage Sci., v.68, p.395-407, 2013.

HUMPHREYS, L.R. Tropical pasture utilisation. Cambridge: Cambridge University Press, 1991. 206p.

KEPHART, K.D.; BUXTON, D.R. Forage quality responses of $\mathrm{C}_{3}$ and $\mathrm{C}_{4}$ perennial grasses to shade. Crop Sci., v.33, p.831-837, 1993.

KOTTEK, M.; GRIESER. J.; BECK, C. et al. World map of the Köppen-Geiger climate classification updated. Meteorol. Z., v.15, p.259263, 2006.

LUDLOW, M.M.; NG, T.T. Leaf elongation rate in Panicum maximum var. trichoglume following removal of water stress. Aust. J. Plant Physiol., v.4, p.263-272, 1977.

MARTEN, G.C.; SHENK, J.S.; BARTON II, F.E. Near infrared reflectance spectroscopy (NIRS), analysis of forage quality. Washington: USDA, ARS, 1989. 110p. (Agriculture Handbook 643).

MURGUEITIO, E.; CALLE, Z.; URIBE, F. et al. Native trees and shrubs for the productive rehabilitation of tropical cattle ranching lands. Forest Ecol. Manag., v.261, p.1654-1663, 2011.

NANDAL, D.P.; RANA, P.; KUMAR, A. Growth and yield of wheat (Triticum aestivum) under different tree spacings of Dalbergia sissoo based agrisilviculture. Indian J. Agron., v.44, p.256260, 1999.

NEEL, J.P.S.; FELTON, E.E.D.; SINGH, S. et al. Open pasture, silvopasture and sward herbage maturity effects on nutritive value and fermentation characteristics of cool-season pasture. Grass Forage Sci., v.71, p.259-269, 2016.

OLIVEIRA, C.C.; ALVES, F.V.; ALMEIDA, R.G. et al. Thermal comfort indices assessed in integrated production systems in the Brazilian savannah. Agroforest. Syst., v.92, p.1659-1672, 2018. 
OLIVEIRA, C.C.; VILLELA, S.D.J.; ALMEIDA, R.G. et al. Performance of Nellore heifers, forage mass, and structural and nutritional characteristics of Brachiaria brizantha grass in integrated production systems. Trop. Anim. Health Prod., v.46, p.167-172, 2014.

PACIULLO, D.S.C.; CASTRO, C.R.T.; GOMIDE, C.A.M. et al. Soil bulk density and biomass partitioning of Brachiaria decumbens in a silvopastoral system. Sci. Agric., v.67, p.598603, 2010.

PACIULLO, D.S.C.; GOMIDE， C.A.M.; CASTRO, C.R.T. et al. Morphogenesis, biomass and nutritive value of Panicum maximum under different shade levels and fertilizer nitrogen rates. Grass Forage Sci., v.72, p.590-600, 2017.

PACIULLO, D.S.C.; PIRES, M.F.A.; AROEIRA, L.J.M. et al. Sward characteristics and performance of dairy cows in organic grasslegume pastures shaded by tropical trees. Animal, v.8, p.1264-1271, 2014.
SHELTON, H.M.; HUMPHREYS, L.R.; BATELLO, C. Pastures in the plantations of Asia and the Pacific: performance and prospect. Trop. Grassl., v.21, p.159-168, 1987.

SOUSA, L.F.; MAURÍCIO, R.M.; MOREIRA, G.R. et al. Nutritional evaluation of "Braquiarão" grass in association with "Aroeira" trees in a silvopastoral system. Agroforest. Syst., v.79, p.189-199, 2010.

WILSON, J.R. Shade-stimulated growth and nitrogen uptake by pasture grasses in a subtropical environment. Aust. J. Agric. Res., v.47, p.10751093, 1996.

YAMAMOTO, W.; DEWI, I.A.; IBRAHIM, M. Effects of silvopastoral areas on milk production at dual-purpose cattle farms at the semi-humid old agricultural frontier in central Nicaragua. Agric. Syst., v.94, p.368-375, 2007.

YOUNG, A. Agroforestry for soil management. 2.ed. Wallingford, UK: CAB International, 1997. 320 p. 